\title{
Developmental time of immature forms of Sabethes aurescens Lutz (Diptera, Culicidae) from artificially perforated bamboo in the rain forest of southern Brazil
}

\author{
Gerson Azulim Muller ${ }^{1}$, Mario Antônio Navarro-Silva ${ }^{1} \&$ Carlos Brisola Marcondes ${ }^{2}$
}

\begin{abstract}
'Laboratório de Entomologia Médica e Veterinária, Departamento de Zoologia, Universidade Federal do Paraná, 81531-980 Curitiba-PR, Brazil. gecoazul@ hotmail.com; mnavarro@ufpr.br

${ }^{2}$ Departamento de Microbiologia e Parasitologia, Universidade Federal de Santa Catarina, 88040-900 Florianópolis-SC, Brazil. cbrisola@mbox1.ufsc.br
\end{abstract}

\begin{abstract}
Developmental time of immature forms of Sabethes aurescens Lutz (Diptera, Culicidae) from artificially perforated bamboo in the rain forest of southern Brazil. The development time of the immature forms of Sabethes aurescens Lutz, 1905, from perforated bamboo in the southern Brazil rain forest was studied under laboratory conditions. Mean development periods were $5 \pm 2.23,10 \pm 5.20,14 \pm 8.26,36 \pm 13.90$ and $9 \pm 2.43$ days, respectively, for the four larval instars and pupae. The $4^{\text {th }}$ instar of females was longer than that of males. Implications of the long development time of the immature forms of Sa. aurescens are discussed.
\end{abstract}

KEYWORDS. Atlantic Forest; Larvae; Phytotelmata.

RESUMO. Tempo de desenvolvimento de formas imaturas de Sabethes aurescens Lutz (Diptera, Culicidae) provenientes de bambus artificialmente perfurados em floresta atlântica do sul do Brasil. O tempo de desenvolvimento de formas imaturas de Sabethes aurescens Lutz, 1905 de bambus perfurados da floresta atlântica do sul do Brasil foi estudado em condições de laboratório. O período médio de desenvolvimento foi de $5 \pm 2,23 ; 10 \pm 5,20 ; 14 \pm 8,26 ; 36 \pm 13,90$ e $9 \pm 2,43$ dias respectivamente, para os quatro instares larvais e pupa. $\mathrm{O} 4^{\circ}$ instar das fêmeas foi mais longo do que o dos machos. Implicações do longo tempo de desenvolvimento das formas imaturas de Sa. aurescens são discutidas.

PALAVRAS-CHAVE. Fitotelmata; Larva; Mata Atlântica.

Mosquitoes of Sabethes Robineau-Desvoidy develop in perforated bamboo internodes and treeholes, which are phytotelmata, defined by Greeney (2001) as the water held by plants. The information about the biology of these mosquitoes has been restricted to the transmission of yellow fever virus. The biology of Sa. chloropterus Humboldt, 1818 was studied in Panama, Trinidad and Brazil (Galindo 1958; Forattini 1965; Chadee 1990), and the genetics and ontogeny of Sa. cyaneus Fabricius, 1805 were studied, respectively, by Munstermann \& Marchi (1986) and Harbach (1991).

Forest fragments in the Atlantic forest of southern Brazil include several species of bamboo native or introduced, mostly in the genus Bambusa (Filgueiras \& Gonçalves 2004) which, when perforated, may be invaded by sylvatic fauna, including Sabethes aurescens Lutz, 1905 (Zequi \& Lopes 2001). Bamboos are among the most specialized habitats for immature mosquitoes (MacDonald \& Traub 1960).

Although Sa. aurescens has not been incriminated as a vector of any arbovirus, it is one of the predominant species and one of the first colonizers in phytotelmata, with an important role in the associated insect fauna (e.g. other species of mosquitoes, flower flies and Gnat flies) (Lozovei 2001).

The association of this species with breeding habitats in perforated bamboo internodes has been studied in several types of vegetation: ombrophylous dense forest (Lozovei 1998), mixed ombrophylous forest (Marcondes et al. 2006) and seasonal semideciduous forest (Zequi \& Lopes 2001). However, the biology of its immature forms is poorly known. The present study intends to examine the period for development of larvae and pupae of Sa. aurescens, which are common in perforated bamboo internodes at Atlantic forest of southern Brazil (Marcondes \& Mafra 2003).

\section{MATERIALAND METHODS}

Samplings of immature forms of Sa. aurescens were carried out in a stand of bamboos, Bambusa tuldoides Munro, 1868, situated at $27^{\circ} 31^{\prime} 44.0^{\prime \prime} \mathrm{S} 48^{\circ} 30^{\prime} 39.2^{\prime \prime} \mathrm{W}$, Desterro Environmental Conservation Unit (UCAD), in Florianópolis municipality, in the State of Santa Catarina, in southern Brazil. The unit has 491.5 ha and is covered by dense ombrophylous forest in several stages of regeneration (Bonnet \& Queiroz 2006).

Holes, five-millimetres wide, were produced by an electric driller, in eight internodes of each of eight bamboo plants (Marcondes \& Mafra 2003) in January 2005. After one month, all the internodes were cut and the water collected and examined in the Laboratory of Medical Entomology of Department of Microbiology and Parasitology (Federal 
University of Santa Catarina). The water sampled was discarded after one month of observation.

An initial expedition for the drilling of eight bamboo internodes in each of eight bamboos, in January 2005, was followed by 12 monthly expeditions, in which the internodes were cut, obtaining water from them. In all expeditions, examination of internodes was followed by the drilling of other internodes, from February 2005 to January 2006. Larvae were maintained in individual $15-\mathrm{ml}$ vials, with distilled water and ground fish food (Tetramin ${ }^{\mathrm{TM}}$ ). The period for the development of each instar was measured from the first moult in the laboratory. Temperature in the laboratory was similar to that in the city, varying from 4.0 to $33.7^{\circ} \mathrm{C}$ (EPAGRI/INMET Station 124, São José, SC).

The larval and pupal development was observed daily. Emerged adults were identified with the key of Forattini (2002). Those immature forms that died before reaching the adult stage, plus all the exuviae, were preserved for identification. All the material was deposited in the collection of the above-cited laboratory. Statistical analyses, including arithmetic means, standard deviation, data range, test for normality (ShapiroWilks) and analysis of variance (ANOVA), were performed by the software Statistica 6.0 (StatSoft Inc 2005).

\section{RESULTS ANDDISCUSSION}

Of 1,357 Sa. aurescens larvae obtained from the bamboo internodes, 1,067 developed to adults, resulting in a mortality of $21.31 \%$. Of these adults, 535 were males and 532 were females

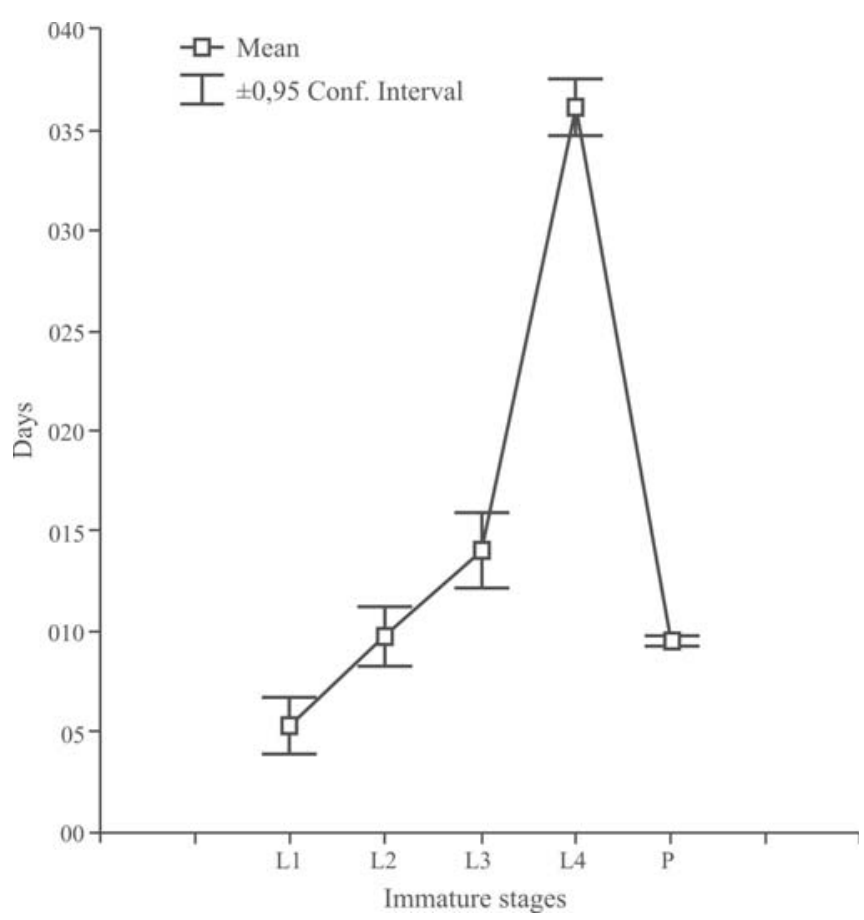

Fig. 1. Developmental periods of larval and pupal stages of Sabethes aurescens collected in bamboo internodes in Atlantic Forest in the Florianópolis, Santa Catarina, Brazil, and reared in laboratory.

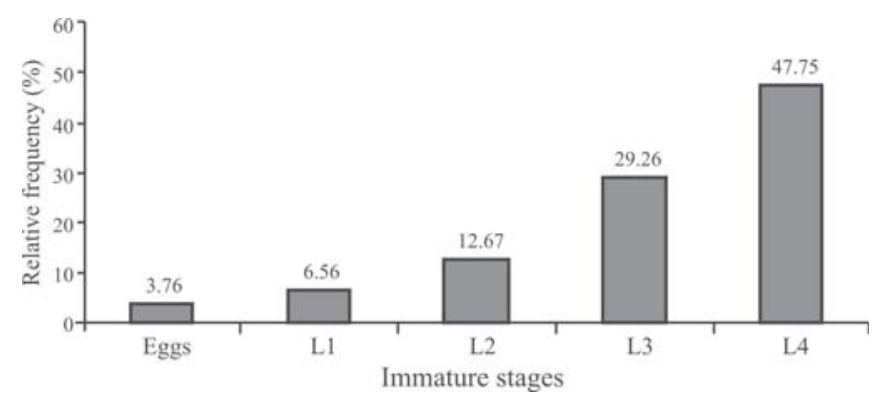

Fig. 2. Relative frequency of different developmental periods of immature stages of Sabethes aurescens collected from February 2005 to January 2006 in internodes of Bambusa tuldoides from Atlantic Forest in the Florianópolis, Santa Catarina, Brazil.

(1:1 sex ratio). Developmental periods in days were as follows: $\mathrm{L}_{1}=5 \pm 2.23, \mathrm{~L}_{2}=10 \pm 5.20, \mathrm{~L}_{3}=14 \pm 8.26, \mathrm{~L}_{4}=36 \pm 13.90$ and $\mathrm{P}=9 \pm 2.43$ (Table I).

Periods for the development of larvae were gradually longer from first to fourth instar, and those for pupae were shorter (Fig. 1). Fifty per cent of first-instar larvae completed their development in 1-5 days and $50.00 \%$ in 6-10 days; in the second instar, $59.61 \%$ completed it in 6-10 days; in the third, $35.44 \%$ completed it in 11-20 days; and in the fourth, $51.39 \%$ completed it in 21-40 days. Development of $63.72 \%$ of pupae was completed in 6-10 days (Table II).

This study was conducted under variable temperature conditions, more similar to those in the bamboo internodes than to those in controlled studies (e.g. Love \& Whelchel 1955; Toma \& Miyagi 1992). Because temperature is an important factor for the development of immature forms, the influence of temperature variation on developmental periods was taken into account by the more realistic conditions of the current study. Besides fluctuations in temperature, periodic exposure to light also can influence development periods (Silveira-Neto et al. 1976).

The observed period for the development of Sa. aurescens (74 days, Table I) was much longer than that of $S a$. chloropterus in the laboratory, which was 14.8 (9-28) days, at temperatures from 24 to $30^{\circ} \mathrm{C}$; the development curve for the last specie was bimodal, with that for the third instar being shorter than that for the second (Galindo 1958). The developmental periods of immature mosquitoes are usually 8 10 days, but those species in small, stable breeding places, such as bamboo internodes, spend more time to complete

Table I. Developmental periods of immature stages of Sabethes aurescens taken from bamboos internodes in Atlantic Forest in the Florianópolis, Santa Catarina, Brazil and reared in the laboratory.

\begin{tabular}{llll}
\hline Instar & Observed $(\mathrm{N})$ & Mean \pm sd (days) & Range (days) \\
\hline $\mathrm{L}_{1}$ & 12 & $5 \pm 2.23$ & $2-9$ \\
$\mathrm{~L}_{2}$ & 52 & $10 \pm 5.20$ & $4-26$ \\
$\mathrm{~L}_{3}$ & 79 & $14 \pm 8.26$ & $4-38$ \\
$\mathrm{~L}_{4}$ & 360 & $36 \pm 13.90$ & $7-80$ \\
Pupa & 962 & $9 \pm 2.43$ & $3-18$ \\
\hline
\end{tabular}




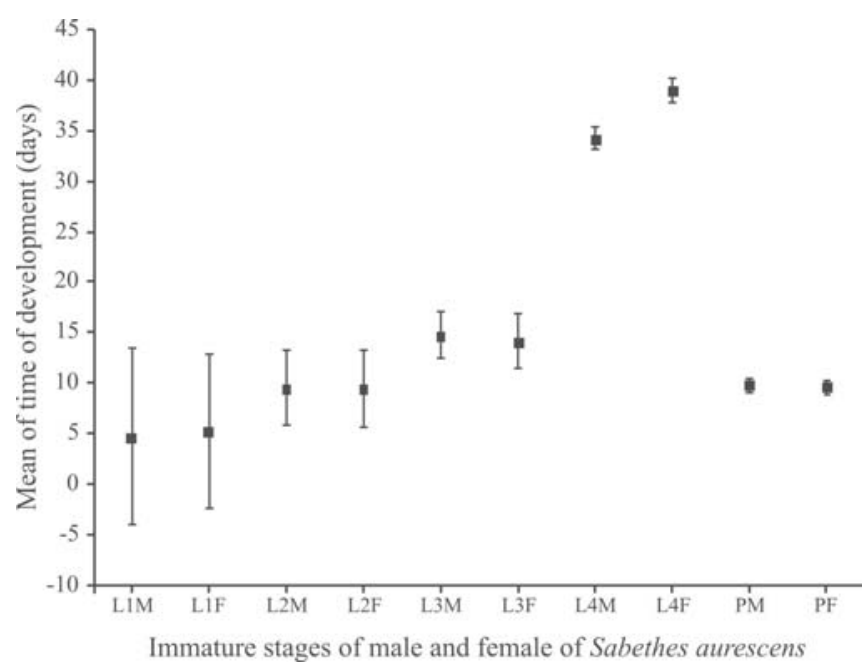

Fig. 3. Sexual variation in time of development for males and females (F- males; $\mathrm{M}$ - males) collected in bamboo internodes in Atlantic Forest in the Florianópolis, Santa Catarina, Brazil (vertical bars denote 0.95 confidence intervals).

development (Forattini 2002). However, the slower development may increase the risk of predation by Toxorhynchites (Lopes 1997), very frequent in our studies (Marcondes \& Mafra 2003).

Most larvae of Sa. aurescens were obtained under natural conditions, except those developing from collected eggs, which could not be noticed until the eggs hatched. Therefore, part of their development occurred in the field and part in the laboratory, under similar conditions (e.g., $47.8 \%$ of larvae were collected in $4^{\text {th }}$ instar; Fig. 2). These are the first observations on the biology of the species in partially artificial conditions.

The period of development of the fourth instar of males was significantly shorter than that of females (Fig. 3). The shorter period for the development of males, compared to that of females, is probably due to the need of rotation of external genitalia (24h after the adult emergence), which will permit the copulation (Forattini 2002). Protandry has been documented among most species of mosquitoes examined, such as the cosmopolitan disease vectors and pests Culex quinquefasciatus Say, 1823 (DeMeillon et al. 1967) and Aedes vexans (Meigen, 1830) (Brust 1967).

Two-hundred ninety larvae were collected in summer, 359 in autumn, 429 in winter and 279 in spring; the differences in abundance among seasons was not significant $(\mathrm{F}=0.852$; $\mathrm{df}=$ $3 \mathrm{p}>0.05$ ). This absence of significant differences among the seasons indicates that females of $\mathrm{Sa}$. aurescens do not alter their egg-laying behavior in different seasons.

Immature forms of Sabethes chloropterus (Humbodt, 1819), which develop in tree holes, have a variable occurrence through the year, with abundance peaks in the rainiest months (Navarro \& Machado-Allison 1995). Contrarily to tree holes, which have a high evaporation index, drilled bamboo internodes are more isolated, maintaining the level of water more constant (Forattini 2002). In summary, Sa. aurescens has a large development period, mostly in $4^{\text {th }}$ instar, utilizing perforated internodes for oviposition during all the year at Atlantic forest of southern Brazil.

Acknowledgments. For allowing access to the UCAD we thank Aldaléa Sprada Tavares and EPAGRI Florianópolis. We also thank CNPq, for a Ph. D. scholarship for GAM and Mr. Silvanio Guilherme da Costa for help in the field work at UCAD. To Dr. Jonny Edward Duque for their constructive criticism. This study is part of the Project "Internal dynamics of rain forest: specificity of animal-plant interaction" within the Brazilian-German program "Mata Atlântica", and we acknowledge the financial support by BMBF (01LB0205) and CNPq (690143/01-0).

\section{REFERENCES}

Bonnet, A. \& M. H. Queiroz. 2006. Estratificação vertical de bromélias epifíticas em diferentes estádios sucessionais da Floresta Ombrófila Densa, Ilha de Santa Catarina, Santa Catarina, Brasil. Revista Brasileira de Botânica 29: 217-228.

Brust, R. A. 1967. Weight and development time of different stadia of mosquitoes reared at various constant temperatures. The Canadian Entomologist 99: 986-993.

Chadee, D. D. 1990. Seasonal abundance and diel landing periodicity of Sabethes chloropterus (Diptera: Culicidae) in Trinidad, West Indies. Journal of Medical Entomology 27: 1041-1044.

DeMeillon, B.; A. Sebastian. \& Z. H. Khan. 1967. Cane-sugar feeding in Culex pipiens fatigans. Bulletin of the World Health Organization 36: 53-65.

Filgueiras, T. S. \& A. P. S. Gonçalves. 2004. A Checklist of the Basal Grasses and Bamboos in Brazil (Poaceae). Journal of the American Bamboo Society 18: 7-18.

Forattini, O. P. 1965. Entomología médica. Culicini: Haemagogus, Mansonia, Culiseta, Sabethini, Toxorhynchitini, Arboviroses, Filariose bancroftiana, Genética. V. 3. São Paulo, EDUSP, 507 p.

Forattini, O. P. 2002. Culicidologia Médica: identificação,

Table II. Developmental periods of immature forms of Sabethes aurescens collected in bamboo internodes in Atlantic Forest in the Florianópolis, Santa Catarina, Brazil and reared in laboratory conditions.

\begin{tabular}{cccccc}
\hline $\begin{array}{c}\text { Periods } \\
(\text { days })\end{array}$ & $\mathrm{L}_{1}$ & $\mathrm{~L}_{2}$ & $\mathrm{~L}_{3}$ & $\mathrm{~L}_{4}$ & $\mathrm{Pupa}$ \\
$\mathrm{N}(\%)$ & $\mathrm{N}(\%)$ & $6(11.54 \%)$ & $9(11.39 \%)$ & $0(0.00 \%)$ & $\mathrm{N}(\%)$ \\
\hline $1-5$ & $6(50.00 \%)$ & $31(59.61 \%)$ & $26(32.91 \%)$ & $6(1.67 \%)$ & $613(63.72 \%)$ \\
$6-10$ & $6(50.00 \%)$ & $11(21.16 \%)$ & $28(35.44 \%)$ & $41(11.39 \%)$ & $317(32.95 \%)$ \\
$11-20$ & $0(0.00 \%)$ & $4(7.69 \%)$ & $16(20.26 \%)$ & $185(51.39 \%)$ & $0(0.00 \%)$ \\
$21-40$ & $0(0.00 \%)$ & $0(0.00 \%)$ & $0(0.00 \%)$ & $128(35.55 \%)$ & $0(0.00 \%)$ \\
$41-80$ & $0(0.00 \%)$ & $52(100 \%)$ & $79(100 \%)$ & $360(100 \%)$ & $962(100 \%)$ \\
Total & $12(100 \%)$ & & & & \\
\hline
\end{tabular}


biologia e epidemiologia. São Paulo, EDUSP, V. 2., 860 p.

Galindo, P. 1958. Bionomics of Sabethes chloropterus Humboldt, a vector of sylvan yellow fever in Middle America. American Journal of Tropical Medicine and Hygiene 7: 429-440.

Greeney, H. F. 2001. The insects of plant-held waters: a review and bibliography. Journal of Tropical Ecology 17: 241-260.

Harbach, R. E. 1991. Ontogeny of the larval stage of Sabethes chloropterus, with special reference to setal development and phylogenetic implications for the family Culicidae (Diptera). Mosquito Systematics 23: 10-23.

Lopes, J. 1997. Ecologia de mosquitos (Diptera:Culicidae) em criadouros naturais e artificiais de área rural do norte do estado do Paraná, Brasil. V. Coleta de larvas em recipientes artificiais instalados em mata ciliar. Revista de Saúde Pública 31: 370-377.

Love, G. J. \& J. G. Whelchel. 1955. Photoperiodism and the development of Aedes triseriatus (Diptera: Culicidae). Ecology 36: $340-342$.

Lozovei, A. L. 1998. Mosquitos dendrícolas (Diptera, Culicidae) em internódios de taquara na Floresta Atlântica, Serra do Mar e do Primeiro Planalto, Paraná, Brasil. Brazilian Archives of Biology and Technology 41: 501-508.

Lozovei, A. L. 2001. Microhabitats de mosquitos (Diptera, Culicidae) em internódios de taquara na Mata Atlântica, Paraná, Brasil. Iheringia, Série Zoologia 90: 3-13.

MacDonald, W. W. \& R. Traub. 1960. Malaysian parasites XXXVIII. An introduction to the ecology of the mosquitoes of the lowland dipterocarp forest of Selangor, Malaya. Studies from the Institute for Medical Research, Malaysia 29: 79-110.
Marcondes, C. B. \& H. Mafra. 2003. Nova técnica para o estudo da fauna de mosquitos (Diptera: Culicidae) em internódios de bambus, com resultados preliminares. Revista da Sociedade Brasileira de Medicina Tropical 36: 763-764.

Marcondes, C. B.; A. Fernandes. \& G. A. Muller. 2006. Mosquitoes (Diptera: Culicidae) near a reservoir in the Western part of the Brazilian State of Santa Catarina. Biota Neotropica 6: http:// w w w. bi o t a n e ot r o p i c a.org.b r / v $6 \mathrm{n} 3 / \mathrm{pt} /$ abstract?inventory+bn02606032006, last access in September of 2008.

Munstermann, L. \& A. Marchi. 1986. Cytogenetic and isoenzyme profile of Sabethes cyaneus. Journal of Heredity 77: 214-248.

Navarro, J. C. \& C. Machado-Allison. 1995. Aspectos ecologicos de Sabethes chloropterus (Humboldt) (Diptera: Culicidae) en un bosque humedo del Edo. Miranda, Venezuela. Boletin de Entomologia Venezolana 10: 91-104.

Silveira-Neto, S.; O. Nakano; D. Barbin. \& N. Villa Nova. 1976. Manual de ecologia dos insetos. São Paulo, Agronômica Ceres, 419 p.

StatSoft Inc. 2005. STATISTICA. (data analysis software system). Tulsa.

Toma, T. \& I. Miyagi. 1992. Laboratory evaluation of Toxorhynchites splendens (Diptera: Culicidae) for predation of Aedes albopictus mosquito larvae. Medical and Veterinary Entomology 6: 281 289.

Zequi, J. A. C. \& J. Lopes. 2001. Culicideofauna (Diptera) encontrada em entrenós de taquara de uma mata residual na área urbana de Londrina, Paraná, Brasil. Revista Brasileira de Zoologia 18: 429-438.

Received 18/09/2008; accepted 15/10/2009 